\title{
Root Growth, Nutrient Uptake and Yield of Medicinal Rice Njavara under Different Establishment Techniques and Nutrient Sources
}

\author{
S. Rani, P. Sukumari \\ Department of Agronomy, TNAU, Coimbatore, India. \\ Email: malarrani@rediffmail.com \\ Received May $31^{\text {st }}, 2013$; revised June $30^{\text {th }}, 2013$; accepted July $15^{\text {th }}, 2013$ \\ Copyright (C 2013 S. Rani, P. Sukumari. This is an open access article distributed under the Creative Commons Attribution License, \\ which permits unrestricted use, distribution, and reproduction in any medium, provided the original work is properly cited.
}

\begin{abstract}
Field experiments with medicinal rice Njavara were conducted at Cropping Systems Research Centre, Karamana, Thiruvananthapuram, Kerala during summer of 2007 and 2008. The experimental design was split plot with three replications. The treatments consisted of four establishment techniques viz., System of Rice Intensification SRI $\left(\mathrm{M}_{1}\right)$, Integrated Crop Establishment Method (ICM) $\left(\mathrm{M}_{2}\right)$, Package of practices (PoP) $\left(\mathrm{M}_{3}\right)$ of Kerala Agricultural University and Conventional Management Practices (CMP) $\left(\mathrm{M}_{4}\right)$ in main plot. Three nutrient sources viz., (1) organic, 2) integrated use of organic and inorganic, 3) chemical fertilizers only) were used under different establishment techniques. Root dry matter production was determined at weekly intervals and plant nutrients uptake was determined by calculating from the product of dry matter, straw dry weight, grain yield and percentage of nutrients. Results revealed that at early stages (4 - 6 WAT/WAS) (Weeks after transplanting/Weeks after sowing), root dry matter production hill ${ }^{-1}$ was in the order of SRI $>$ ICM $>$ CMP $>$ PoP which changed to SRI $>$ ICM $>$ PoP $>$ CMP from $7^{\text {th }}$ week onwards. Maximum root dry matter (at $\left.9^{\text {th }} \mathrm{WAS} / \mathrm{WAT}\right)$ was recorded in SRI $\left(0.51 / 0.50 \mathrm{~g} \cdot \mathrm{hill}^{-1}\right.$ in $\left.2007 / 2008\right)$. The total nutrients uptake $(\mathrm{N}, \mathrm{P}, \mathrm{K}, \mathrm{Fe}$, $\mathrm{Mn}$ and $\mathrm{Zn}$ ) in conventional management practices was significantly higher than other establishment techniques. Among the nutrient sources, higher total (N, P, K, Fe, Mn and Zn) uptake by crop was recorded under integrated nutrient source than organic and inorganic sources.
\end{abstract}

Keywords: Njavara Rice; Establishment Techniques; Nutrient Sources; Root Growth; Total Nutrient Uptake; Yield

\section{Introduction}

Rice is an important crop and will continue to play a vital role in food security for millions of people in India. The future of Indian food security and foreign exchange through rice exports will also largely depend on desired production and productivity. Opportunities are great for attaining high yield in rice through proper agronomic management practices, low cost mechanization in seeding, weeding and suitable establishment techniques [1]. Njavara is widely used in the Ayurvedic System of Medicine, especially in treating Panchakarma. Njavara as a special cereal, has the properties to rectify the basic ailments affecting circulatory, respiratory and the digestive systems.

The water and nutrient uptake ability of plants highly depends on the root architecture [2], while the root system directly affects the amount of water available to crop. Most of crops largely rely on stored water into the soil profile. The root systems of rice consist of seminal and nodal roots with first- and higher-order lateral roots. The rootlength can penetrate from 70 to $80 \mathrm{~cm}$ in soil. However, the lowland rice has got a shallow and compact root system, most of which is distributed in the top $15 \mathrm{~cm}$ of soil [3]. The soil moisture has a profound impact on root growth, viability, functionality and plant growth [4]. The deep extensive root enhances water utilization in the deeper soil profile, which is considered to be an important trait of drought resistance in plants. The present study was to investigate the developmental phenology of Njavara root growth and its nutrient uptake under different establishment techniques and nutrient sources.

\section{Materials and Methods}

\subsection{Site and Soil Description}

Field experiments were conducted for two consecutive 
years i.e., summer/third crop/puncha season of 2007 and 2008 at Cropping Systems Research Centre, Karamana, Thiruvananthapuram, Kerala. The soil was acidic in reaction $(5.5 \mathrm{pH})$, high in organic carbon content $(1.23 \%)$, medium in available nitrogen $\left(261.9 \mathrm{~kg} \cdot \mathrm{ha}^{-1}\right)$, available phosphorus $\left(22.0 \mathrm{~kg} \cdot \mathrm{ha}^{-1}\right)$ and available potassium $(140.2$ $\left.\mathrm{kg} \cdot \mathrm{ha}^{-1}\right)$ status.

\subsection{Experimental Treatments and Design}

The experiment was laid out in a split plot design with three replications. The establishment techniques in main plot were SRI (System of Rice Intensification) $\left(\mathrm{M}_{1}\right), \mathrm{ICM}$ (Integrated Crop Establishment Method) $\left(\mathrm{M}_{2}\right)$, PoP (Package of Practices) $\left(\mathrm{M}_{3}\right)$ (Recommendation of Kerala Agricultural University) as well as the Conventional Management Practices $\left(\mathrm{M}_{4}\right)$ and nutrient sources viz., organic sources $\left(\mathrm{S}_{1}\right)$, integrated nutrient sources $\left(\mathrm{S}_{2}\right)$ and inorganic sources $\left(\mathrm{S}_{3}\right)$ in sub plot.

\subsection{Crop Husbandry}

In SRI treatments single, eight day old seedlings were transplanted at $20 \times 20 \mathrm{~cm}$ spacing. Four weedings with rotary weeder were given at 10 days interval starting from 10 DAT to panicle initiation (45 days). Soil was kept at field capacity up to panicle initiation and then onwards $5 \mathrm{~cm}$ standing water was allowed in the field till 10 days before harvesting. In ICM treatments two seedlings of 12 days age were transplanted at $20 \times 20 \mathrm{~cm}$ spacing. Two rotary weedings on 10 and 20 DAT were given followed by one hand weeding on 35 DAT. A thin film of water was kept in the field till 10 days before harvesting. In PoP treatments three seedlings of 18 days age were transplanted at $15 \times 10 \mathrm{~cm}$ spacing. Weed control was achieved through one manual weeding on 15 DAT and application of 2,4-D @ $1 \mathrm{~kg}$ a.i ha ${ }^{-1}$ on 25 DAT. Water level was maintained at about $1.5 \mathrm{~cm}$ during transplanting. Thereafter it was increased gradually to about 5 $\mathrm{cm}$. intermittent draining and reflooding was done. Field was drained 10 days before harvesting. In conventional management practicespre germinated seeds were broadcasted @ $80 \mathrm{~kg} \cdot \mathrm{ha}^{-1}$. A thin film of water was maintained up to 10 DAS after which water level was raised up to 5 $\mathrm{cm}$ and field was drained 10 days before harvest. Two manual weedings were done at 15 and 35 DAS.

\subsection{Manures and Fertilizers}

Nutrient management recommendation of Package of Practices: Crops (2007) of Kerala Agricultural University was adopted. For wet land local varieties the recommenddation is $5 \mathrm{t} \mathrm{FYM} \mathrm{+} \mathrm{40:20:20} \mathrm{kg} \mathrm{NPK} \mathrm{per} \mathrm{ha.} \mathrm{Full}$ $\mathrm{FYM}+2 / 3 \mathrm{~N}+$ Full $\mathrm{P}+1 / 2 \mathrm{~K}$ were to be applied as basal.
$1 / 3 \mathrm{~N}+1 / 2 \mathrm{~K}$ were to be applied at panicle initiation. Three types of nutrient management were involved in the technical programme. In the organic treatments 40:20:20 kg NPK ha ${ }^{-1}$ were supplied through FYM, rock phosphate and wood ash. 5t FYM ha ${ }^{-1}$ was also applied. In integrated nutrient management treatments $40: 20: 20 \mathrm{~kg}$ NPK $h^{-1}$ were supplied through urea, rock phosphate and muriate of potash along with 5t FYM. In the inorganic treatments NPK contribution by 5t FYM was calculated and they were supplied through urea, rock phosphate and muriate of potash. NPK was also applied at the rate of 40:20:20 kg $\cdot \mathrm{ha}^{-1}$ respectively.

\subsection{Data Recording}

\subsubsection{Root Drymatter Production}

Root biomass production from five sample plants collected from sampling area were recorded on dry weight basis and the average worked out at weekly interval from fourth week of transplanting/sowing till physiological maturity.

\subsubsection{Plant Analysis}

Sample plants collected from each plot at harvest were separated into straw and grain, sun dried, and then oven dried to a constant weight and the samples were ground, digested and used for analysis of nutrient content. Nutrient uptake was worked out using the following equation and expressed as $\mathrm{kg} \cdot \mathrm{ha}^{-1}$.

\begin{tabular}{|c|c|}
\hline Nutrients & Determination methods \\
\hline Nitrogen & Microkjeldahl method [5] \\
\hline Phosphorus & $\begin{array}{l}\text { Diacid extract estimated colorimetrically in a } \\
\text { Spectronic-20 Spectrophotometer by } \\
\text { Vanadomolybdophosphoric yellow colour } \\
\text { method [5] }\end{array}$ \\
\hline Potassium & Diacid extract method using Flame photometer [5] \\
\hline $\mathrm{Fe}, \mathrm{Mn}$ and $\mathrm{Zn}$ & $\begin{array}{l}\text { Diacid extract method using atomic absorption } \\
\text { spectrophotometer (Perkin Elmer model) [5] }\end{array}$ \\
\hline Sulphur & $\begin{array}{l}\text { Turbidimetric method using Spectronic-20 } \\
\text { spectrophotometer [6] }\end{array}$ \\
\hline
\end{tabular}

$$
\begin{aligned}
& \text { Nutrient uptake } \\
& =\frac{\text { Nutrient content } \times \text { Dry matter production }}{100}
\end{aligned}
$$

\subsubsection{Grain and Straw Yield}

The net plot area was harvested individually, threshed, winnowed, dried, weighed and expressed in $\mathrm{kg} \cdot \mathrm{ha}^{-1}$. Straw harvested from each net plot was dried in sun and the weight expressed in $\mathrm{kg} \cdot \mathrm{ha}^{-1}$.

\subsubsection{Statistical Analysis}

Data recorded during the field investigation were statis- 
tically analyzed with split plot design method as suggested by [7] for test of significance. Wherever the treatment differences were found significant, the critical differences were worked out to 5 per cent probability level and the values furnished.

\section{Results and Discussion}

\subsection{Effect of Rice Establishment Techniques and Nutrient Source on Root Dry Matter Production}

Root dry matter production in Njavara was significantly influenced by rice establishment techniques. Root dry matter hill $^{-1}$ was recorded at weekly interval from $4^{\text {th }}$ WAT/WAS till physiological maturity. At the early stages (4 - $6 \mathrm{WAT} / \mathrm{WAS})$ root dry matter production hill $^{-1}$ was in the order SRI $>$ ICM $>$ conventional management practices $>$ PoP which changed to SRI $>$ ICM $>$ PoP $>$ conventional management practices from $7^{\text {th }}$ week onwards (Table 1). Throughout the crop growth period, all the establishment techniquesdiffered significantly from one another in root dry matter hill ${ }^{-1}$. Increase in root dry matter occurred up to $9 \mathrm{WAS} / \mathrm{WAT}$ (Weeks after transplanting/Weeks after sowing). Higher root dry matter (at $9^{\text {th }}$ WAS/WAT) was recorded in SRI $(0.51 /$ $0.50 \mathrm{~g} \mathrm{hill}^{-1}$ in $\left.2007 / 2008\right)$ and it was $21 / 25 \%$ higher in 2007/ 2008 than ICM $\left(0.42 / 0.60 \mathrm{~g} \cdot \mathrm{hill}^{-1}\right.$ in $\left.2007 / 2008\right)$ and $31 / 32 \%$ higher in $2007 / 2008$ than PoP $(0.39 / 0.38$ $\mathrm{g} \cdot \mathrm{hill}^{-1}$ in $2007 / 2008$ ) and $59 / 52 \%$ higher in $2007 / 2008$ than conventional management practices $(0.32 / 0.33$ $\mathrm{g} \cdot \mathrm{hill}^{-1}$ in 2007/2008), respectively.

Increase in root dry matter in SRI and ICM may be attributed to increased aeration in soil due to stirring of soil by rotary weeder. Rotary weeder was operated four times in SRI treatments and two times in ICM treatments. Till $6^{\text {th }}$ week, root dry matter production in conventional management practices was higher than that in PoP which may be attributed to the earlier establishment and root development in the broadcast crop. But from 7th week onwards root development occurred at faster rate in PoP compared to conventional management practices which might be due to availability of more space for individual hill under transplanted condition. This would have reduced the competition for nutrients and water as reported by [8] planting of single seedling rather than in clumps helped to avoid root competition and promoted vigorous root growth. [9] reported that following a wider spacing $25 \times 25 \mathrm{~cm}$ and early and frequent weeding using a mechanical weeder encouraged the proliferation of microorganisms that symbiotically enhanced the capacity of plants to produce more tillers, with vigorous and healthy root growth and a large number of panicles heavily laden with grains. Root development was least in conventional management practice which combined with least culm strength might have resulted in lodging of the crop. Less interplant competition would have enabled the plants to

Table 1. Effect of rice establishment techniques and nutrient sources on root dry matter production hill ${ }^{-1}$.

\begin{tabular}{|c|c|c|c|c|c|c|c|c|c|c|c|c|c|c|c|c|}
\hline \multicolumn{17}{|c|}{ Root dry matter production hill ${ }^{-1}(\mathrm{~g})$} \\
\hline Treatments & \multicolumn{2}{|c|}{$4^{\text {th }}$ week } & \multicolumn{2}{|c|}{$5^{\text {th }}$ week } & \multicolumn{2}{|c|}{$6^{\text {th }}$ week } & \multicolumn{2}{|c|}{$7^{\text {th }}$ week } & \multicolumn{2}{|c|}{$8^{\text {th }}$ week } & \multicolumn{2}{|c|}{$9^{\text {th }}$ week } & \multicolumn{2}{|c|}{$10^{\text {th }}$ week } & \multicolumn{2}{|c|}{ Physiological Maturity } \\
\hline Management systems & 2007 & 2008 & 2007 & 2008 & 2007 & 2008 & 2007 & 2008 & 2007 & 2008 & 2007 & 2008 & 2007 & 2008 & 2007 & 2008 \\
\hline $\mathrm{M}_{1}(\mathrm{SRI})$ & 0.26 & 0.26 & 0.30 & 0.31 & 0.38 & 0.35 & 0.44 & 0.45 & 0.45 & 0.47 & 0.51 & 0.50 & 0.51 & 0.50 & 0.51 & 0.50 \\
\hline $\mathrm{M}_{2}(\mathrm{ICM})$ & 0.17 & 0.17 & 0.28 & 0.27 & 0.31 & 0.31 & 0.31 & 0.30 & 0.42 & 0.42 & 0.42 & 0.40 & 0.42 & 0.40 & 0.41 & 0.40 \\
\hline $\mathrm{M}_{3}(\mathrm{PoP})$ & 0.15 & 0.14 & 0.18 & 0.17 & 0.20 & 0.21 & 0.29 & 0.28 & 0.33 & 0.32 & 0.39 & 0.38 & 0.38 & 0.38 & 0.36 & 0.37 \\
\hline $\mathrm{M}_{4}(\mathrm{CMP})$ & 0.16 & 0.17 & 0.20 & 0.19 & 0.22 & 0.23 & 0.25 & 0.26 & 0.28 & 0.28 & 0.32 & 0.33 & 0.32 & 0.30 & 0.27 & 0.28 \\
\hline SEd & 0.01 & 0.01 & 0.01 & 0.01 & 0.01 & 0.01 & 0.01 & 0.01 & 0.00 & 0.01 & 0.01 & 0.01 & 0.01 & 0.01 & 0.01 & 0.01 \\
\hline CD (0.05) & 0.01 & 0.01 & 0.01 & 0.01 & 0.01 & 0.01 & 0.02 & 0.01 & 0.02 & 0.02 & 0.02 & 0.02 & 0.03 & 0.02 & 0.02 & $\mathbf{0 . 0 3}$ \\
\hline \multicolumn{17}{|c|}{ Nutrient sources } \\
\hline $\mathrm{S}_{1}$ (Organic) & 0.19 & 0.19 & 0.24 & 0.24 & 0.28 & 0.28 & 0.33 & 0.33 & 0.37 & 0.38 & 0.41 & 0.40 & 0.41 & 0.40 & 0.40 & 0.39 \\
\hline $\mathrm{S}_{2}$ (Integrated) & 0.19 & 0.19 & 0.24 & 0.23 & 0.27 & 0.27 & 0.32 & 0.32 & 0.37 & 0.37 & 0.41 & 0.40 & 0.41 & 0.40 & 0.38 & 0.38 \\
\hline $\mathrm{S}_{3}$ (Inorganic) & 0.18 & 0.18 & 0.23 & 0.23 & 0.27 & 0.27 & 0.32 & 0.32 & 0.36 & 0.36 & 0.40 & 0.40 & 0.41 & 0.40 & 0.38 & 0.38 \\
\hline SEd & 0.01 & 0.01 & 0.01 & 0.01 & 0.01 & 0.02 & 0.01 & 0.01 & 0.01 & 0.01 & 0.01 & 0.01 & 0.01 & 0.01 & 0.01 & 0.02 \\
\hline CD (0.05) & NS & NS & NS & NS & NS & NS & NS & NS & NS & NS & NS & NS & NS & NS & NS & NS \\
\hline
\end{tabular}

SRI-System of Rice Intensification; ICM —-Integrated Crop Establishment Method Package of Practices; PoP—Package of Practices of Kerala Agricultural University; CMP — Conventional Management Practices. 
have more physiological activity. In square planting with wider spacing soil area was available for foraging leading to improved root characters viz., root length, root volume and root dry weight resulting in more photosynthetic activity. This might be reason for higher root and straw dry matter in SRI. Similar result was reported by $[10]$.

\subsection{Effect of Rice Establishment Techniques and Nutrient Source on Nutrient Uptake}

Nutrient uptake by grain, straw and total uptake by crop showed more or less the same trend in both seasons. The total nutrient uptake (N, K, Fe, Mn and $\mathrm{Zn}$ ) were in the order CMP $>$ PoP $>$ SRI $>$ ICM. Total P uptake was in the order CMP $>$ SRI $>$ PoP $>$ ICM. Total uptake of all the nutrients in conventional management practices was significantly higher $\left(20.42 \mathrm{~kg} \cdot \mathrm{ha}^{-1}\right.$ in 2007 and 2008 (N uptake), 1.93/2.20 kg.ha- in 2007 and 2008 (P uptake), 25.98/28.56 $\mathrm{kg} \cdot \mathrm{ha}^{-1}$ in 2007 and 2008 (K uptake), $0.99 / 1.06 \mathrm{~kg} \cdot \mathrm{ha}^{-1}$ in 2007 and 2008 (Fe uptake), $1.00 / 1.08 \mathrm{~kg} \cdot \mathrm{ha}^{-1}$ in 2007 and 2008 (Zn uptake) and $1.04 / 1.11 \mathrm{~kg} \cdot \mathrm{ha}^{-1}$ in 2007 and 2008 (Mn uptake) than that in the other three establishment techniques (Tables 2 and 3). Uptake of all nutrients in PoP and ICM were at par and as well as that in SRI and ICM. [11] reported that total nutrient uptake in broadcast seeded flooded rice was higher than that in transplanted rice due to transplant shock, lower plant density and higher $\mathrm{N}$ losses in transplanted rice.

Nutrient sources showed significant influence on total uptake by the crop ( $\mathrm{P}, \mathrm{K}, \mathrm{Fe}$ and $\mathrm{Zn})$ in both seasons Nutrient sources showed no significant influence on total $\mathrm{N}, \mathrm{S}$ and $\mathrm{Mn}$ uptake. Highest $\mathrm{P}$ uptake (1.82/1.89 $\left.\mathrm{kg} \cdot \mathrm{ha}^{-1}\right), \mathrm{K}$ uptake $\left(24.11 / 26.38 \mathrm{~kg} \cdot \mathrm{ha}^{-1}\right)$, Fe uptake $\left(0.93 / 1.00 \mathrm{~kg} \cdot \mathrm{ha}^{-1}\right)$ and $\mathrm{Zn}$ uptake $\left(1.02 / 1.06 \mathrm{~kg} \cdot \mathrm{ha}^{-1}\right)$ by the crop (grain + straw) occurred. In integrated nutrient source and organic and inorganic source results were at par. [12] stated that integrated nutrient management is the best approach to supply adequate and balanced nutrients and increase crop productivity in an efficient and environmentally benign manner, without sacrificing soil productivity of future generations. $[13,14]$ reported that uptake of nutrients was improved by the application of integrated use of organic and inorganic fertilizer compared to RDF.

\subsection{Effect of Rice Establishment Techniques and Nutrient Source on Yield}

Higher grain yield was recorded in conventional management practices $\left(\mathrm{M}_{4}\right)\left(1041.4 / 1038.4 \mathrm{~kg} \cdot \mathrm{ha}^{-1}\right.$ in $2007 / 2008$ ) and was $16 \% / 15 \%$ higher in $2007 / 2008$ than PoP, $24 \% / 26 \%$ higher in $2007 / 2008$ than in SRI and $36 \% / 37 \%$ higher in 2007/2008 than ICM (Table 4). The highest grain yield $\left(928.7 / 920.5 \mathrm{~kg} \cdot \mathrm{ha}^{-1}\right.$ in $\left.2007 / 2008\right)$ was obtained in integrated nutrient source $\left(\mathrm{S}_{2}\right)$ which was followed by organic source $\left(872.1 / 857.9 \mathrm{~kg} \cdot \mathrm{ha}^{-1}\right.$ in $2007 /$ 2008 ) and inorganic source $\left(857.3 / 857.5 \mathrm{~kg} \cdot \mathrm{ha}^{-1}\right.$ in 2007/2008), respectively. Significant higher grain yield realized in conventional management practices could be attributed to the better growth and yield parameters

Table 2. Effect of rice establishment techniques and nutrient sources on N, P, K and S uptake ((kg·ha $\left.{ }^{-1}\right)$.

\begin{tabular}{|c|c|c|c|c|c|c|c|c|}
\hline \multirow{2}{*}{$\begin{array}{c}\text { Treatments } \\
\text { Management systems }\end{array}$} & \multicolumn{2}{|c|}{$\mathbf{N}$ uptake $\left(\mathbf{k g} \cdot \mathbf{h a}^{-1}\right)$} & \multicolumn{2}{|c|}{ P uptake $\left(\mathrm{kg} \cdot \mathrm{ha}^{-1}\right)$} & \multicolumn{2}{|c|}{ K uptake $\left(\mathrm{kg} \cdot \mathrm{ha}^{-1}\right)$} & \multicolumn{2}{|c|}{ S uptake $\left(\mathrm{kg} \cdot \mathrm{ha}^{-1}\right)$} \\
\hline & 2007 & 2008 & 2007 & 2008 & 2007 & 2008 & 2007 & 2008 \\
\hline $\mathrm{M}_{1}(\mathrm{SRI})$ & 16.56 & 15.54 & 1.57 & 1.53 & 20.47 & 20.93 & 1.85 & 1.71 \\
\hline $\mathrm{M}_{2}(\mathrm{ICM})$ & 14.62 & 14.08 & 1.44 & 1.36 & 17.99 & 19.67 & 1.76 & 1.58 \\
\hline $\mathrm{M}_{3}(\mathrm{PoP})$ & 17.45 & 16.71 & 1.56 & 1.56 & 21.09 & 23.47 & 1.93 & 1.95 \\
\hline $\mathrm{M}_{4}(\mathrm{CMP})$ & 20.42 & 20.42 & 1.93 & 2.20 & 25.98 & 28.56 & 2.46 & 2.22 \\
\hline SEd & 0.92 & 0.89 & 0.10 & 0.13 & 1.07 & 1.31 & 0.29 & 0.29 \\
\hline CD (0.05) & 2.10 & 2.02 & 0.11 & 0.29 & 2.42 & 2.97 & NS & NS \\
\hline \multicolumn{9}{|l|}{ Nutrient sources } \\
\hline $\mathrm{S}_{1}$ (Organic) & 18.35 & 17.56 & 1.63 & 1.88 & 20.33 & 20.44 & 1.78 & 1.93 \\
\hline $\mathrm{S}_{2}$ (Integrated) & 15.90 & 15.78 & 1.82 & 1.89 & 24.11 & 26.38 & 2.05 & 2.21 \\
\hline $\mathrm{S}_{3}$ (Inorganic) & 17.55 & 16.73 & 1.42 & 1.44 & 19.72 & 22.65 & 1.77 & 1.86 \\
\hline SEd & 1.02 & 0.87 & 0.05 & 0.11 & 1.61 & 1.29 & 0.34 & 0.18 \\
\hline CD (0.05) & NS & NS & 0.10 & 0.22 & 3.32 & 2.66 & NS & NS \\
\hline
\end{tabular}


Table 3. Effect of rice establishment techniques and nutrient sources on Fe, Zn and Mn uptake (kg·ha $\left.{ }^{-1}\right)$.

\begin{tabular}{|c|c|c|c|c|c|c|}
\hline \multirow{2}{*}{$\begin{array}{c}\text { Treatments } \\
\text { Management systems }\end{array}$} & \multicolumn{2}{|c|}{ Fe uptake $\left(\mathrm{kg} \cdot \mathrm{ha}^{-1}\right)$} & \multicolumn{2}{|c|}{ Zn uptake $\left(\mathrm{kg} \cdot \mathrm{ha}^{-1}\right)$} & \multicolumn{2}{|c|}{ Mn uptake $\left(\mathrm{kg} \cdot \mathrm{ha}^{-1}\right)$} \\
\hline & 2007 & 2008 & 2007 & 2008 & 2007 & 2008 \\
\hline $\mathrm{M}_{1}(\mathrm{SRI})$ & 0.74 & 0.75 & 0.76 & 0.81 & 0.78 & 0.81 \\
\hline $\mathrm{M}_{2}(\mathrm{ICM})$ & 0.65 & 0.69 & 0.68 & 0.73 & 0.70 & 0.74 \\
\hline $\mathrm{M}_{3}(\mathrm{PoP})$ & 0.78 & 0.83 & 0.81 & 0.88 & 0.84 & 0.88 \\
\hline $\mathrm{M}_{4}(\mathrm{CMP})$ & 0.99 & 1.06 & 1.00 & 1.08 & 1.04 & 1.11 \\
\hline SEd & 0.05 & 0.05 & 0.05 & 0.06 & 0.06 & 0.06 \\
\hline $\mathrm{CD}(0.05)$ & 0.11 & 0.12 & 0.11 & 0.14 & 0.13 & 0.14 \\
\hline \multicolumn{7}{|l|}{ Nutrient sources } \\
\hline $\mathrm{S}_{1}$ (Organic) & 0.63 & 0.66 & 0.74 & 0.81 & 0.77 & 0.81 \\
\hline $\mathrm{S}_{2}$ (Integrated) & 0.93 & 1.00 & 1.02 & 1.06 & 0.91 & 0.97 \\
\hline $\mathrm{S}_{3}$ (Inorganic) & 0.81 & 0.83 & 0.68 & 0.76 & 0.85 & 0.87 \\
\hline SEd & 0.10 & 0.13 & 0.04 & 0.05 & 0.10 & 0.12 \\
\hline CD (0.05) & 0.26 & 0.22 & 0.09 & 0.11 & NS & NS \\
\hline
\end{tabular}

Table 4. Effect of rice establishment techniques and nutrient sourcesyield attributes of Njavara rice.

\begin{tabular}{|c|c|c|c|c|c|c|}
\hline \multirow[b]{2}{*}{ Treatments } & \multicolumn{2}{|c|}{ Number of tillers $\mathbf{m}^{-2}$} & \multicolumn{2}{|c|}{ Grain yield $\left(\mathrm{kg} \cdot \mathrm{ha}^{-1}\right)$} & \multicolumn{2}{|c|}{ Straw yield $\left(\mathrm{kg} \cdot \mathrm{ha}^{-1}\right)$} \\
\hline & 2007 & 2008 & 2007 & 2008 & 2007 & 2008 \\
\hline \multicolumn{7}{|c|}{ Management systems } \\
\hline $\mathrm{M}_{1}(\mathrm{SRI})$ & 96.0 & 95.5 & 1235 & 1210 & 840.8 & 821.6 \\
\hline $\mathrm{M}_{2}(\mathrm{ICM})$ & 146.7 & 146.7 & 1126 & 1115 & 764.7 & 756.2 \\
\hline $\mathrm{M}_{3}(\mathrm{PoP})$ & 591.1 & 587.8 & 1338 & 1324 & 897.3 & 899.7 \\
\hline $\mathrm{M}_{4}(\mathrm{CMP})$ & 981.4 & 976.4 & 1685 & 1697 & 1041.4 & 1038.4 \\
\hline SEd & 4.02 & 2.16 & 15.68 & 15.43 & 9.41 & 9.28 \\
\hline CD (0.05) & 9.10 & 4.88 & 35.47 & 34.89 & 21.29 & 20.99 \\
\hline \multicolumn{7}{|l|}{ Nutrient sources } \\
\hline $\mathrm{S}_{1}$ (Organic) & 454.7 & 450.7 & 1285 & 1266 & 872.1 & 857.9 \\
\hline $\mathrm{S}_{2}$ (Integrated) & 452.0 & 451.5 & 1494 & 1496 & 928.7 & 920.5 \\
\hline $\mathrm{S}_{3}$ (Inorganic) & 453.9 & 452.7 & 1258 & 1246 & 857.3 & 857.5 \\
\hline SEd & 3.96 & 2.16 & 14.26 & 34.89 & 9.25 & 9.06 \\
\hline CD (0.05) & NS & NS & 29.42 & 28.59 & 19.10 & 18.71 \\
\hline
\end{tabular}

realized in this treatment compared to other establishment techniques. Significant growth characters like leaf number per plant, leaf area index and tiller number per unit area might have resulted in increased photosynthesis and production resulting of photosynthates which finally transformed into high number of panicles per unit area and thereafter higher relative accumulation of dry matter.
Straw yield also showed the same trend like grain yield in establishment techniques and nutrient sources.

\section{Conclusion}

All the tillers produced in SRI were productive tillers and $91 \%$ of the tillers produced in ICM bore panicles. Uptake 
of all the nutrients in conventional management practices was significantly higher than that in the other three establishment techniques. Highest total nutrient $(\mathrm{P}, \mathrm{K}, \mathrm{Fe}$ and $\mathrm{Zn}$ ) uptake by crop (grain + straw) occurred in integrated nutrient source. Maximum root dry matter (at $9^{\text {th }}$ WAS/WAT) was recorded in SRI and root development was least in conventional management practices which combined with least culm strength might have resulted in lodging of the crop.Tiller per unit area in SRI practices was found to be the minimum which limit the uptake of nutrients, while in case of conventional management practices it was found to be vise versa.

\section{REFERENCES}

[1] M. N. Budhar, "Farmers Get Their Groove Back Rice Today," International Rice Research Institute Bulletin, Philippines, 2011, pp. 33-35.

[2] J. Lynch, "Root Architecture and Plant Productivity," Plant Physiology, Vol. 109, 1995, pp. 7-13.

[3] S. Morita, S. Yamada and J. Abe, "Analysis on Root System Morphology in Rice with Reference to Varietal Differences at Ripening Stage," Japanese Journal of Crop Science, Vol. 64, 1995, pp. 58-65. doi: $10.1626 /$ jcs. 64.58

[4] B. R. Huang, "Water Relations and Root Activities of Buchloe Dactyloides and Zoysia Japonica in Response to Localized Soil Drying," Plant and Soil, Vol. 208, No. 2, 1999, pp. 179-186. doi:10.1023/A:1004472314631

[5] M. L. Jackson, "Soil Chemical Analysis," Prentice Hall of India Inc., New Delhi, 1973, p. 170.

[6] C. H. Willium and A. Steinbergs, "Soil Sulphur Fractions as Chemical Indices of Available Sulphur in Some Australian Soils," Australian Journal of Agricultural Re- search, Vol. 100, 1959, pp. 340-352.

[7] K. A. Gomez and A. A. Gomez, "Statistical Procedures for Agricultural Research," 2nd Edition, John Wiley and Sons, New York, 1984, p. 680.

[8] N. Uphoff and R. Randriamiharisoa, "Reducing Water Use in Irrigated Rice Production with the Madagascar System of Rice Intensification (SRI)," Proceedings of the International Workshop on Water-Wise Rice Production, IRRI, Los Banos, 2002, pp. 71-87.

[9] S. Anitha, "System of Rice Intensification," Kissan World, Vol. 56, 2005, p. 41.

[10] M. D. Shrirame, H. J. Rajgire and A. H. Rajgiri, "Effect of Spacing and Seedling Number per Hill on Growth Attributes and Yield of Rice Hybrids under Lowland Condition," Journal of Soil and Crops, Vol. 10, No. 1, 2000, pp. 109-113.

[11] N. Nabheerong, "Root Growth and Nutrient Uptake of Rices as Affected by Planting Methods and Green Manures," Kasetsart Journal: Natural Science, Vol. 27, 1992, pp. 358-388.

[12] A. Ayalew and T. Dejene, "Combined Application of Organic and Inorganic Fertilizers to Increase Yield of Barley and Improve Soil Properties at Fereze in Southern Ethiopia," Innovative Systems Design and Engineering, Vol. 3, No. 1, 2012, pp. 25-35.

[13] S. Mithun, S. S. Mondal, D. Acharya and S. Sanjoy, "Effect of Integrated Nutrient Management on Productivity and Quality of Basmati Rice (Oryza sativa L.)," Oryza, Vol. 44, No. 2, 2007, pp. 125-129.

[14] S. Srinivasan and A. Angayarkanni, "Effect of INM on Yield and Nutrient Uptake by Rice in STCR Experiment," Agricultural Science Digest, Vol. 28, No. 2, 2008, pp. 130-132. 